Article

\title{
Effectiveness and Energy Requirements of Pasteurisation for the Treatment of Unfiltered Secondary Effluent from a Municipal Wastewater Treatment Plant
}

\author{
Peter Sanciolo ${ }^{1, *}$, Paul Monis ${ }^{2}$, Justin Lewis ${ }^{3}$, Greg Ryan ${ }^{4}$, Andrew Salveson ${ }^{5}$, \\ Nicola Fontaine ${ }^{5}$, Judy Blackbeard ${ }^{3}$ and Stephen Gray ${ }^{1}$ (D) \\ 1 Institute for Sustainable Industries and Liveable Cities, Victoria University, \\ Melbourne 3000, Victoria, Australia; Stephen.Gray@vu.edu.au \\ 2 Australian Water Quality Centre, SA Water Corporation, Adelaide 5000, South Australia, Australia; \\ Paul.Monis@sawater.com.au \\ 3 Melbourne Water, Melbourne 3000, Victoria, Australia; Justin.Lewis@melbournewater.com.au (J.L.); \\ Judy.Blackbeard@melbournewater.com.au (J.B.) \\ 4 PTG Water and Energy, Larkspur, CA 94939, USA; gryan@pastechgroup.com \\ 5 Carollo Engineers, Walnut Creek, CA 94598, USA; ASalveson@carollo.com (A.S.); \\ NFontaine@carollo.com (N.F.) \\ * Correspondence: Peter.Sanciolo@vu.edu.au
}

Received: 12 June 2020; Accepted: 21 July 2020; Published: 24 July 2020

\begin{abstract}
Pasteurisation was investigated as a process to achieve high microbial quality standards in the recycling of water from unfiltered secondary effluents from a wastewater treatment plants in Melbourne, Australia. The relative heat sensitivity of key bacterial, viral, protozoan and helminth wastewater organisms (Escherichia coli, Enterococcus, FRNA bacteriophage, adenovirus, coxsackievirus, Cryptosporidium, and Ascaris) were determined by laboratory scale tests. The FRNA phage were found to be the most heat resistant, followed by enterococci and E. coli. Pilot scale challenge testing of a $2 \mathrm{ML} /$ day pasteurisation pilot plant using unfiltered municipal wastewater and male specific coliphage (MS2) phage showed that temperatures between $69^{\circ} \mathrm{C}$ and $75^{\circ} \mathrm{C}$ achieved log reductions values between $0.9 \pm 0.1$ and $5.0 \pm 0.5$ respectively in the contact chamber. Fouling of the heat exchangers during operation using unfiltered secondary treated effluent was found to increase the energy consumption of the plant from $2.2 \mathrm{kWh} / \mathrm{kL}$ to $5.1 \mathrm{kWh} / \mathrm{kL}$. The economic feasibility of pasteurisation for the current municipal application with high heat exchanger fouling potential can be expected to depend largely on the available waste heat from co-generation and on the efforts required to control fouling of the heat exchangers.
\end{abstract}

Keywords: pasteurisation; pasteurization; disinfection by-product; municipal wastewater; wastewater recycling

\section{Introduction}

Recycled water is widely used in Australia for various purposes such as toilet flushing, domestic gardening, irrigation of parks and sportsgrounds, and in peri-urban agriculture. Due to the high risk of direct human exposure to the water, or to incidental ingestion of the water, the highest level of treatment (Class A) is required for this recycled water. The microbial water quality objectives for Class A water are determined by a quantitative microbial risk assessment (QMRA), consistent with the Australian Guidelines for Water Recycling [1]. The ability of a treatment process to render the water safe to use for a specific purpose is a key feature of the QMRA. This is commonly determined by 
the performance in challenge tests. Other key features of the QMRA are the feed water quality and variability, the likely level of exposure, and infection rates of pathogens.

The safe treatment of sewage and the delivery of safe recycled water for reuse or for environmental discharge requires a considerable energy input. Energy use is largely in the form of electricity to run pumps and other process equipment, and for disinfection if the water is to be reused. Under financial pressures from growing energy costs and regulatory pressures to reduce greenhouse gas emissions, many wastewater treatment plants are keen to implement renewable energy sources and improve the energy efficiency of their operations. The on-site electricity generation from biogas gives rise to large quantities of waste heat that can be utilised for other processes, such as disinfection via pasteurisation.

Wastewater pasteurisation (WP) is an emerging disinfection technology that may have considerable cost and environmental advantages over traditional wastewater treatment processes. It can utilise waste heat from on-site electricity generation using biogas or gas from city or community supply to heat the wastewater for inactivating the pathogens of concern. Pasteurisation technology has been extensively used in the food industry for many years but its large-scale application to wastewater treatment has emerged only recently. In the US, WP technology was granted California Title 22 approval for disinfection of filtered secondary effluent in 2007 [2]. It has been demonstrated at the city of Santa Rosa's Laguna Wastewater Reclamation Plant, where validation testing was conducted as part of the California Department of Public Health (CDPH, now called the Division of Drinking Water (DDW)) program to review new technologies for wastewater treatment for water reuse and provide conditional approval (often referred to as "Title 22" approval) [3]. More recently, WP technology has been adopted in the northern California town of Graton [2]. The adoption of this technology in the US state of California for the treatment of filtered effluent suggests that that it may have economic and/or environmental advantages (i.e., fewer disinfection by-products) over more established wastewater disinfection technology. It is, however, difficult to find supporting evidence of this in the peer-reviewed scientific literature, and the performance of WP for treatment of unfiltered secondary effluent is not documented.

One of the advantages of using pasteurization to disinfect wastewater is that it does not lead to harmful effects of unreacted disinfectant chemicals and to the formation of harmful disinfection by-products (DBPs). Chlorination and ozonation are currently commonly used for wastewater disinfection and their extensive use has led to the production of very harmful DBPs. The DBPs from chlorination are harmful to both humans and the environment, and cause measurable effect of acute toxicity from even low levels of residual chlorine [4-6]. The DBPs from ozonation result from the oxidation of halogens, leading to the formation of carcinogens such as bromate at concentrations as low as $20 \mu \mathrm{g} / \mathrm{L}$ [7]. The other commonly used wastewater disinfection method, UV disinfection, has not been shown to lead to measurable quantities of DBPs [8]. The UV disinfection of turbid wastewater with low UV transmittance, however, requires powerful UV systems that are both capital and energy intensive, and necessitate pre-treatment to reduce turbidity and organic content.

The heating of pathogens brings about denaturation of macromolecules and structures that are required for microbial function. The extent of denaturation of pathogen macromolecules, and the resulting inactivation of pathogens, depends on both temperature and time. The higher the temperature, the less time is required for this denaturation to take place. Wastewater contains a wide variety of pathogens, each with its own tolerance to heat, and the required heat treatment for disinfection is that which can kill even the most tolerant of these pathogens. Furthermore, the salt content, the phase of growth of the organisms, the solution $\mathrm{pH}$ and the presence of suspended solid matter may have a protective effect. Salt content of the order of 1 to $2 \% w / v$ has been found to be protective to bacteria and viruses [9-12]. Bacteria in late stationary phase of growth have been found to be more heat resistant than $\log$ phase cells [13]. Bacterial resistance to heat has been found higher for acid grown bacteria than for cells grown at higher $\mathrm{pH}$ values [14]. Performance of the WP process has been reported to be worse in unfiltered feedwaters than in filtered feedwaters [15]. 
Due to the large rate of production of wastewater from most municipal wastewater treatment plants, WP technology usually needs to operate at high flow rates which, in turn, requires high temperatures and short contact time to achieve the desired level of inactivation. The selection of the appropriate temperature and contact time to inactivate even the most heat resistant of pathogens requires knowledge of the heat tolerance of the wide variety of pathogens present in the wastewater. Once the most heat resistant organism is known, this organism can be tested for in the treated water and can be used as a surrogate for the other organisms of concern and an indicator of plant performance. This research identified the most heat tolerant organisms in the various classes of organisms (bacteria, virus, protozoa and helminths) found in wastewater and then experimentally tested their tolerance to heat in different wastewater matrices, allowing the selection of appropriate surrogate organisms for industrial-scale challenge testing of existing WP technology. Key to the economic viability of the WP process is the harnessing of waste heat from on-site electricity generation and the use of efficient heat exchangers that recycle the heat and cool the treated water close to the ambient temperature before discharge. This research also quantified the decrease in efficiency of the WP process, as fouling of the heat exchangers occurred during the treatment of unfiltered secondary effluent with high fouling potential. This work also examined the efficacy of different clean in place (CIP) procedures in restoring heat exchanger efficiency.

\section{Materials and Methods}

\subsection{Laboratory Scale Testing}

The literature-derived inactivation temperatures for selected pathogens and surrogates [16] were verified by laboratory-scale testing. The temperatures and exposure times that were going to be used in the $2 \mathrm{ML} /$ day pilot system were also used as a further consideration for selection of the inactivation temperatures and times evaluated in the laboratory-scale testing. Experiments were conducted using waters collected from Melbourne's Western Treatment Plant (WTP) and Eastern Treatment Plant (ETP). The effect of temperature and time $\left(55^{\circ} \mathrm{C}, 65^{\circ} \mathrm{C}\right.$ and $\left.75^{\circ} \mathrm{C}, 5 \mathrm{~s}, 30 \mathrm{~s}, 60 \mathrm{~s}\right)$ was evaluated for wastewater sampled from different steps of the treatment process (i.e., from Pond Two (P2) and Pond 10 (P10) of a 10 pond maturation treatment process). Experiments were also conducted to determine if the origin of the test organism (laboratory reference strain or wastewater isolate) had any influence on temperature inactivation. Inactivation experiments placed $120 \mu \mathrm{L}$ samples into $0.2 \mathrm{~mL}$ tubes, which were incubated in a thermal cycler (Palmcycler, Corbett Research, Sydney, Australia). Controls were included to account for any natural die-off at ambient temperature, and to account for any inactivation that occurred while the sample temperature was ramping up from ambient to the target temperature (from room temperature to target temperature with a nominal $1 \mathrm{~s}$ hold at the target temperature). Samples were diluted using sterile reagent-grade water as required for microbiological analysis. Chemical analyses were performed by a commercial analytical laboratory (ALS Water).

\subsubsection{Male Specific Coliphage (MS2) Tests}

The American Public Health Asscociation (APHA) Method 9224C was used for the detection of male-specific coliphage (both FRNA and FDNA), with the exception that $1 \mathrm{~mL}$ of sample was analysed. Plates were incubated at $36^{\circ} \pm 1.0^{\circ} \mathrm{C}$ for $24 \pm 2 \mathrm{~h}$. A suitable reference strain of Escherichia coli (ATCC 700891) was used as the phage host, and laboratory cultured male specific coliphage (MS2) ATCC 15597-B1 was used as reference for FRNA coliphage. Indigenous male-specific coliphage in a $1 \mathrm{~mL}$ wastewater sample were isolated using the phage plating method. The top layer of agar containing phage plaques was scraped from the plate into tryptone soy broth (Oxoid), vortexed and centrifuged to pellet cells/debris/agar. The phage plating method was used to isolate any phage in the supernatant and the process was repeated. Male-specific coliphage include both FRNA and FDNA phage; the abundance of each was determined by plating samples in the presence or absence of RNase. The numbers of FDNA were low in the wastewater samples but increased following isolation of phage 
from the plates. Differential counts (using plates $+/-$ RNase) were used to compare temperature inactivation of indigenous FRNA with MS2.

\subsubsection{Escherichia coli Tests}

A National Association of Testing Authorities (NATA) accredited method, based on Australian Standard AS 4276.7, was used for the isolation and enumeration of E. coli. In brief, this method filters a $100 \mathrm{~mL}$ sample through a membrane, which is then placed onto MI agar (a selective chromogenic medium) and incubated at $30 \pm 0.5^{\circ} \mathrm{C}$ for $4 \mathrm{~h}$ and then at $44.5^{\circ} \mathrm{C} \pm 0.5^{\circ} \mathrm{C}$ for $16 \mathrm{~h} \pm 2 \mathrm{~h}$. Criteria for counting E. coli colonies were used as described in 4276.7 .

\subsubsection{Enterococci Tests}

Intestinal enterococci were enumerated using a NATA accredited method based on Australian Standard AS 4276.9, with the addition of glucosidase agar for confirmation of Enterococcus. This method is also based on filtration of a $100 \mathrm{~mL}$ sample and culture on a chromogenic medium (m-Enterococcus agar). Plates were incubated at $36 \pm 2.0^{\circ} \mathrm{C}$ for $44 \pm 4 \mathrm{~h}$. Presumptive colonies were cultured using glucosidase agar (incubated at $35 \pm 0.5^{\circ} \mathrm{C}$ for up to $4 \mathrm{~h}$ ) and other culture media (as described in more detail in AS 4276.9).

\subsubsection{Coxsackievirus and Adenovirus Tests}

Coxsackievirus and adenovirus were selected as representatives of human enteric viruses. Coxsackie B5 (CB5) (ATCC VR-185) was cultured in buffalo green monkey kidney (BGM) cells; adenovirus 2 ( $\mathrm{Ad} 2$ ) was obtained from the National Institute of Allergy and Infectious Diseases (NIAID) and cultured in human lung adenocarcinoma epithelial (A549) cells. Stocks were prepared by infecting the appropriate cultured mammalian cell line. Cells were cultured to confluence in $175 \mathrm{~cm}^{3}$ flasks infected with the $3 \mathrm{~mL}$ of culture medium without foetal bovine serum (FBS) containing the respective virus at a multiplicity of infection of approximately 1 . Flasks were incubated for $90 \mathrm{~min}$ at $37^{\circ} \mathrm{C}$ in a $\mathrm{CO}_{2}$ incubator, with rocking every $10 \mathrm{~min}$. The inoculum was replaced with $15 \mathrm{~mL}$ of complete medium and incubated at $37^{\circ} \mathrm{C}$ in a $\mathrm{CO}_{2}$ incubator until $>90 \%$ of the cell monolayer had been killed by virus infection. Host cells were subjected to between 1-3 rounds of freeze-thaw to release any cell-associated virus particles. Virus particles were purified by centrifugation $\left(4^{\circ} \mathrm{C}\right.$ at $10,000 \mathrm{~g}$ for $10 \mathrm{~min})$ and filtration $(0.2 \mu \mathrm{m}$ Acrodisc syringe, Pall Corporation, Port Washington, New York, NY, USA). Virus titres were determined using a plaque assay as described by Kahler et al. [17]. Virus stocks were dispensed into $1 \mathrm{~mL}$ aliquots and stored at $-80^{\circ} \mathrm{C}$. The plaque method [17] was also used to enumerate viruses in temperature inactivation experiments. Briefly, cell monolayers were infected with 100 or $200 \mu \mathrm{L}$ of serially diluted $\left(10^{-1}-10^{-6}\right)$ sample. Following infection, cells were washed and overlaid with $2 \%$ SeaPlaque Agarose (Lonza Rockland, Inc., Rockland, Maine, USA) prepared in 2X Minimum Essential Media (MEM) plus 10\% FBS. Inverted plates were incubated at $37^{\circ} \mathrm{C}$ for 3 or 10 days for CB5 or Ad2 respectively. Cells were fixed with $1 \%$ formalin, the overlay was removed and cells were stained with $0.2 \%$ crystal violet. Plaques were counted and infectious viral units were reported as plaque forming units (PFUs) per $\mathrm{mL}$.

\subsubsection{Cryptosporidium Infectivity Test}

Cryptosporidium oocyst infectivity was measured by cell culture using a simplification of the assay described by King et al. [18], which uses fluorescent antibodies to detect cells that have been infected by Cryptosporidium. Each cluster of infected cells (also known as an infectious focus) represents infection initiated by a single infectious oocyst. Temperature inactivation experiments used a predetermined (by fluorescence microscopy) number of infectious oocysts in each sample, which allowed known numbers of oocysts to be used in the infectivity assay, simplifying the calculation of the number of infectious oocycts. The percentage of infectious oocysts after heat treatment (aht) was determined using the 
number of infectious oocysts detected by cell culture and the total number of oocysts applied to cell culture, according to Equation (1):

$$
\% \text { Infectious aht }=100 \times(\text { Cell culture detected } / \text { Total number applied })
$$

In order to avoid any overlap of infectious foci, only 100 oocysts were applied to each cell culture well. The total number of oocysts applied to multiple cell culture wells was used to calculate the maximum log removal values ( $L R V s$ ) for Cryptosporidium.

$$
L R V=\log _{10}(\text { Total oocysts applied })-\log _{10}(\text { Total infectious oocysts aht })
$$

\subsubsection{Helminths Tests}

The method of Jeska et al. [19] was used to isolate Ascaris suum eggs. Pig intestines from slaughtered animals suspected to contain Acaris worms were obtained from the Department of Primary Industries, VIC, Australia. Intact female worms (selected based on size) were rinsed in egg laying solution (phosphate buffered physiological saline ( $\mathrm{pH} 7.3$ ), $0.0015 \mathrm{~N}$ sodium hydroxide and $11 \mathrm{mM}$ glucose), placed in $75 \mathrm{~cm}^{2}$ cell culture flasks with egg laying medium supplemented with $125 \mathrm{mg} / \mathrm{L}$ gentamycin sulfate and incubated at $37^{\circ} \mathrm{C}$ for multiple days. The medium was changed each day to allow collection of any released eggs, which were stored at $4{ }^{\circ} \mathrm{C}$ until required. Eggs were enumerated by light microscopy. Egg viability was determined by measuring the development of larvae. Sample aliquots of $25 \mu \mathrm{L}$ containing approximately 200-300 eggs were mixed with $225 \mu \mathrm{L} 0.1 \mathrm{~N}$ sulphuric acid (Sigma-Aldrich, Sydney, Australia) in a 90 well microplate (Corning, Tewksbury, USA). The plate was incubated in the dark at $22^{\circ} \mathrm{C}$ for 40 days, with the well volume maintained by topping up with distilled water as required. Following incubation, $60-100$ eggs were visually assessed at 100-400 X magnification (CKX41 microscope, Olympus, Tokyo, Japan) for the presence of developmental stages and were assessed and categorized as unfertilized (dark and elongated with incomplete eggshells), pre-larval and developed larvae. The eggs with a larval stage present were deemed viable and percentage calculations excluded unfertilized eggs. Viability was calculated using the following equation:

$$
\% \text { Viability }=100 \times\left(N_{\text {larvae }} /\left(N_{\text {pre-larval stages }}+N_{\text {larvae }}\right)\right)
$$

\subsubsection{Effect of Turbidity Test}

The presence of solids (in the form of particulates) may affect heat transfer and microbial inactivation in the wastewater. To assess this, the turbidity of ETP secondary effluent (2.1 NTU) was artificially increased. The particulates in ETP secondary effluent were concentrated by centrifugation and the resulting pellet added to un-modified ETP secondary effluent, resulting in a turbidity of 14.6 NTU. The number of $E$. coli in the ETP effluent was not sufficient to for inactivation experiments, so indigenous $E$. coli were isolated by membrane filtration of $100 \mathrm{~mL}$ of effluent (as described above). A colony that appeared to originate from a single particle (assessed by dissection microscopy) was sub-cultured using MI agar. This isolate was further subcultured overnight at $37^{\circ} \mathrm{C}$ in $10 \mathrm{~mL}$ of tryptone soy broth (TSB). The overnight culture was re-inoculated into fresh $10 \mathrm{~mL}$ TSB bottles and incubated with shaking for $3-4 \mathrm{~h}$ at $37^{\circ} \mathrm{C}$ until the culture reached an optical density of $0.6-0.8$ absorbance units. The culture $(10 \mathrm{~mL})$ was pelleted by centrifugation and resuspended in $10 \mathrm{~mL}$ of 2.1 NTU or 14.6 NTU ETP pond water.

\subsection{Pilot Plant Testing}

The 2ML/day pasteurisation pilot plant used in this study (Pasteurization Technology Group, PTG) was composed of heat exchangers, stack heater and pipeline contact chamber (see Figure 1). The pathogen inactivation taking place in the contact chamber and in entire pasteurisation plant was tested by challenge testing using MS2 coliphage. 

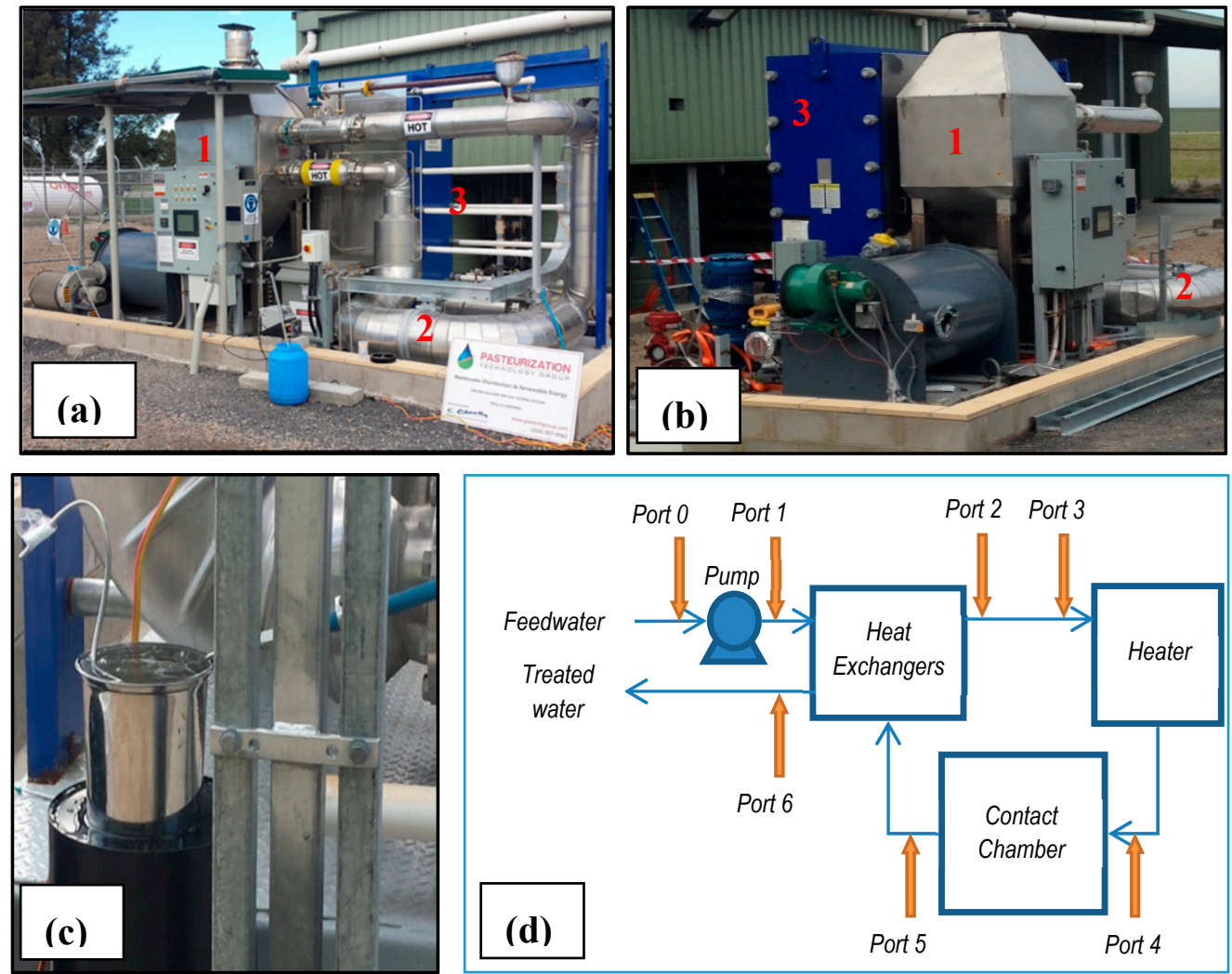

Figure 1. Pasteurisation pilot plant. (a and $\mathbf{b}$ ): frontal view and side view showing key pilot plant components: heater (1), contact chamber (2) and heat exchangers (3); (c): ice bath sample chilling device used for Port 5 samples; and (d): process schematic showing location of sample ports and key pilot plant components.

The feedwater for the pilot plant trial was unfiltered ETP secondary effluent. The feedwater was sampled on the challenge tests days and analyzed by a commercial analytical laboratory (ALS Water). for total organic carbon (TOC), suspended solids (SS), volatile suspended solids (VSS), electrical conductivity (EC), dissolved calcium, $\mathrm{pH}$, alkalinity, turbidity and UV transmittance (UVT).

Rhodamine WT was used as a tracer in determination of the contact time at each tested flow rate. The tracer was injected at low water temperature $\left(19^{\circ} \mathrm{C}\right)$ and detected by fluorescence measurement. The contact time was calculated according to the method outlined in Appendix D of [20].

\subsubsection{Contact Chamber Testing}

The effectiveness of inactivation taking place in the contact chamber was tested by injecting MS2 phage at Port 4 for approximately $20 \mathrm{~min}$ and sampling at Port 5 (see Figure 1) after a minimum total flow equivalent to three times the contact chamber contact times, i.e., after at least $3 \mathrm{~min}$ at $550 \mathrm{~L} / \mathrm{min}$ (60 s contact time), and after at least $1.5 \mathrm{~min}$ at 1,100 L/min ( $30 \mathrm{~s}$ contact time). The pre-treatment MS2 concentration was determined by injection of the MS2 at Port 0 and sampling at Port 6 at ambient temperature $\left(<30^{\circ} \mathrm{C}\right)$ where MS2 phage is known to be unaffected by these low temperatures. The high flow $(\sim 1100 \mathrm{~L} / \mathrm{min})$ tests of the contact chamber were performed on 4 separate days at 3 different temperatures on each day. Six before treatment and six after treatment samples were taken at each temperature, giving a total of 24 before-treatment and 24 after-treatment samples at each temperature for the determination of the bottom 5th percentile log reduction value $(L R V)$ required for validation [21]. One batch of MS2 culture was used on each of the 4 days. The average MS2 concentration before treatment on the 4 separate days varied between 4.0 and $5.5 \mathrm{log}$. The heat in all samples from Port 5 was quenched immediately to between $40^{\circ} \mathrm{C}$ and $50^{\circ} \mathrm{C}$ by passing the sample through a spiral tube in 
an ice bath during sample collection. The samples were subsequently left in an ice bath for a further 5 min to ensure further cooling.

\subsubsection{Whole Plant Testing}

Testing of the performance of the entire process involved the injection of MS2 for approximately $30 \mathrm{~min}$ at a port prior to the feed pump (Port 0, see Figure 1), and sampling at Ports 1 and 6. Sampling was started after flow equivalent to three times the entire plant contact time had passed through the plant following commencement of MS2 dosing, i.e., after $12.7 \mathrm{~min}$ at $1100 \mathrm{~L} / \mathrm{min},(4.2 \mathrm{~min}$ contact time). Six before-treatment and six after-treatment samples were taken at each test temperature. The Port 1 results were used to determine the pre-treatment MS2 concentration. A separate batch of MS2 culture was used for each of the temperatures tested for pathogen inactivation between Ports 1 and 6 . The average MS2 concentration before treatment for the 3 separate temperatures varied between 4.1 and $4.5 \log$.

\subsubsection{Clean in Place}

A clean in place (CIP) was performed on three different days. For each CIP event, the flow rate was set at $1100 \mathrm{~L} / \mathrm{min}$ with the system in recirculation mode. The cleaning chemicals $(46 \% \mathrm{NaOH}$ or $50 \%$ citric acid) were injected into the plant (total Volume $4500 \mathrm{~L}$ ) and kept at $60{ }^{\circ} \mathrm{C}$ for $60 \mathrm{~min}$. The first $\mathrm{CIP}$ used $10 \mathrm{~L}$ of $\mathrm{NaOH}$. The second CIP used $85 \mathrm{~L}$ of $\mathrm{NaOH}$. The third CIP used $85 \mathrm{~L}$ of citric acid.

\section{Results}

\subsection{Water Quality Data}

Water for the laboratory scale testing was collected at two levels of maturation and biological treatment, from the second pond (P2) and the 10th pond (P10) in the Western Treatment Plant (WTP) 10 maturation pond treatment system. The results of microbial and chemical assay of this water are summarised in Table 1.

Table 1. Water quality data for Western Treatment Plant Pond water.

\begin{tabular}{|c|c|c|c|c|}
\hline Month of Sampling & April & April & June & June \\
\hline Pond ID * & P2 & P10 & P2 & P10 \\
\hline Escherichia coli (cfu/100 mL) & 71,000 & 7 & 520,000 & 6 \\
\hline Faecal coliforms (cfu/100 mL) & 71,000 & 29 & 520,000 & 15 \\
\hline Enterococci (cfu/100 mL) & 48,000 & 9 & 23,000 & 0 \\
\hline FRNA $(\mathrm{pfu} / \mathrm{mL})$ & 30 & 680 & - & - \\
\hline $\mathrm{pH}$ & 7.3 & 8.217 & - & - \\
\hline Turbidity (NTU) & 8.5 & 1.879 & - & - \\
\hline Ammonia (mg/L) & 67.8 & $<0.5$ & 63.0 & 0.2 \\
\hline Nitrate+nitrite $(\mathrm{mg} / \mathrm{L})$ & 0.007 & 21.7 & 0.007 & 20.9 \\
\hline Phosphate (mg/L) & 10.9 & 8.988 & 10.9 & 8.4 \\
\hline TKN (mg/L) & 63.8 & 1.659 & 65.5 & 1.7 \\
\hline $\mathrm{DOC}(\mathrm{mg} / \mathrm{L})$ & 15.3 & 8.9 & 17.1 & 8.4 \\
\hline TOC (mg/L) & 21.2 & 10.7 & 29.5 & 9.5 \\
\hline $\mathrm{BOD}(\mathrm{mg} / \mathrm{L})$ & 14 & $<2$ & 24 & $<2$ \\
\hline $\mathrm{COD}(\mathrm{mg} / \mathrm{L})$ & 104 & 223 & 127 & 84 \\
\hline Conductivity (EC) ( $\mu \mathrm{Scm})$ & 2150 & 1860 & 2170 & 1700 \\
\hline TDS (mg/L) & 1200 & 1000 & 1200 & 940 \\
\hline $\mathrm{SS}(\mathrm{mg} / \mathrm{L})$ & 12 & 4 & & \\
\hline VSS (mg/L) & 11 & 2 & - & - \\
\hline
\end{tabular}

${ }^{*} \mathrm{P} 2$, P10 indicates Ponds 2 and 10 respectively of a 10 pond maturation system. 
The quality of the feed water during the pilot scale challenge tests is shown in Table 2. The feed water quality data was plotted against the achieved $L R V$ to assess if any of the measured parameters influenced the $L R V$ achieved during pasteurisation. The square of the Pearson product moment correlation coefficients $\left(\mathrm{R}^{2}\right)$, from highest to lowest, were: $\mathrm{SS}(0.60)>\mathrm{Ca}(0.42),>$ turbidity $(0.38)>\mathrm{TOC}$ $(0.33)>\mathrm{pH}(0.31)>\operatorname{VSS}(0.27)>\operatorname{COD}(0.20)>\mathrm{UVT}(0.16)>$ alkalinity $(0.09)>\mathrm{EC}\left(8 \times 10^{-5}\right)$. Only two of the parameters showed a trendline with a negative slope that would be indicative of a decrease in $L R V$ with increase in the parameter (alkalinity and COD). More data are required to establish whether or not there is a correlation between $L R V$ and the tested water quality parameters, but this lack of clear correlation is consistent with these parameters having no influence over the range of values tested in these trials.

Table 2. Water quality on high flow rate $(1100 \mathrm{~L} / \mathrm{min})$ challenge tests days.

\begin{tabular}{ccccccccccc}
\hline $\begin{array}{c}\text { Test Temperature } \\
\left({ }^{\circ} \mathrm{C}\right)\end{array}$ & $\begin{array}{c}\text { Alkalinity } \\
(\mathbf{m g} / \mathbf{L} \text { as } \\
\left.\mathrm{CaCO}_{3}\right)\end{array}$ & $\mathbf{p H}$ & $\begin{array}{c}\mathrm{Ca} \\
(\mathbf{m g} / \mathbf{L})\end{array}$ & $\begin{array}{c}\text { Turbidity } \\
(\mathbf{N T U})\end{array}$ & $\begin{array}{c}\text { SS } \\
(\mathbf{m g} / \mathbf{L})\end{array}$ & $\begin{array}{c}\mathbf{V S S} \\
(\mathbf{m g} / \mathbf{L})\end{array}$ & $\begin{array}{c}\text { COD } \\
(\mathbf{m g} / \mathbf{L})\end{array}$ & $\begin{array}{c}\text { TOC } \\
(\mathbf{m g} / \mathbf{L})\end{array}$ & $\begin{array}{c}\text { EC } \\
(\mathbf{u S} / \mathbf{c m})\end{array}$ & $\begin{array}{c}\text { UVT } \\
(\%)\end{array}$ \\
\hline $75,72,69,66$ & 60 & 6.6 & 16 & 3.5 & 16 & 6 & 65 & 14 & 850 & 44 \\
\hline $68,64,60,57$ & 42 & 6.6 & 16 & 6.8 & 24 & 6 & 60 & 15 & 830 & 41 \\
\hline $75,72,69$ & 59 & 6.9 & 18 & 4.6 & 24 & 4 & 70 & 15 & 890 & 35 \\
\hline $75,72,69$ & 43 & 6.6 & 16 & 2.3 & 16 & 2 & 50 & 13 & 730 & 43 \\
\hline $75,72,69$ & 53 & 6.7 & 17 & 9 & 23 & 33 & 44 & 16 & 830 & 40 \\
\hline
\end{tabular}

\subsection{Laboratory-Scale Testing}

The primary purpose of the laboratory testing was to provide data for the selection of surrogate agents (i.e., microbial organisms that can be readily enumerated in lieu of the target pathogen). A good conservative surrogate agent for the pasteurisation process is one that is more heat resistant than the target pathogens such that the achieved heat inactivation of the organism of concern is always more than that of the surrogate. A recent survey of heat inactivation of pathogens found that FRNA phage (MS2) is less heat sensitive than E. coli, most viruses and could thus make a conservative surrogates for these pathogens [16]. The relative heat sensitivity of MS2 was compared to that of $E$. coli and other pathogens of concern under conditions relevant to the Pilot Plant. The results of the laboratory scale testing are shown in Tables 3 and 4. MS2 was found to be the most heat resistant, followed by enterococci and E. coli. Ascaris showed some survival at $55^{\circ} \mathrm{C}$ but was totally inactivated at $65^{\circ} \mathrm{C}$. Adenovirus required between 30 and $60 \mathrm{~s}$ for total inactivation at $55^{\circ} \mathrm{C}$. Coxsackievirus B5 and Cryptosporidium were highly temperature sensitive, being rapidly inactivated even after brief time exposures to $55^{\circ} \mathrm{C}$.

A comparison of the inactivation of laboratory and wild strains (Table 3) shows that wastewater isolates of $E$. coli have a similar sensitivity to temperature to that of the laboratory strain. The native FRNA was found to be less heat sensitive than MS2, particularly at $75^{\circ} \mathrm{C}$ for $30 \mathrm{~s}$ exposure (Native FRNA $L R V=\sim 1.5$, MS2 $L R V=\sim 6$ ).

As seen in Table 4, there was also no evidence of any difference in sensitivity due to different water quality, with similar results for MS2 phage, E. coli or Chryptosporidium spiked into P2 (8.5 NTU) or P10 water (1.8 NTU), suggesting that turbidity at these levels had no effect. The effect of turbidity was further tested on ETP water. The results are shown in Table 5. Statistical comparison of the LRV results using $t$-tests did not show any significant difference between waters of different turbidity ( $t$-test $p>0.05)$. 
Table 3. Log reduction values achieved in laboratory trials at different temperatures and contact times in Western Treatment Plant (WTP) Pond 2 water.

\begin{tabular}{|c|c|c|c|c|c|c|c|c|c|}
\hline \multirow{3}{*}{ Infectious Agent } & \multicolumn{9}{|c|}{ Temperature $\left({ }^{\circ} \mathrm{C}\right)$} \\
\hline & \multicolumn{3}{|c|}{$\begin{array}{c}55 \\
\text { Contact Time (Seconds) }\end{array}$} & \multicolumn{3}{|c|}{$\begin{array}{c}65 \\
\text { Contact Time (Seconds) }\end{array}$} & \multicolumn{3}{|c|}{$\begin{array}{c}75 \\
\text { Contact Time (Seconds) }\end{array}$} \\
\hline & 5 & 30 & 60 & 5 & 30 & 60 & 5 & 30 & 60 \\
\hline MS2 & & & & 0 & $0.28 \pm 0.10$ * & $1.09 \pm 0.03 *$ & $0.59 \pm 0.43$ * & $>6.24,>6.24 * *, 5.94$ & $>6.24,>6.24,5.94$ \\
\hline FRNA-Wild & & & & 0 & $0.10 \pm 0.15^{*}$ & $0.37 \pm 0.12 *$ & $0.50 \pm 0.20 *$ & $1.63,1.47$ & $>8.01,7.72,>7.96$ \\
\hline Enterococci (wild) & & & & & $0.63 \pm 0.14 *$ & $2.09 \pm 0.40 *$ & $1.78 \pm 1.06^{*}$ & $>5.90$ & $>5.90$ \\
\hline E. coli-Lab & & & & & $2.47 \pm 0.71 *$ & $>6.08,6.91,>4.49$ & & & \\
\hline E. coli-Wild & & & & & $1.37 \pm 0.51^{*}$ & $6.17 \pm 0.95 *$ & & & \\
\hline Ascaris & 0.01 & 0.04 & 0.90 & $>1.79$ & $>1.68$ & $>1.68$ & $>1.83$ & $>1.74$ & $>1.99$ \\
\hline Coxsackievirus & & $5.0,5.2$ & $5.6,6.0$ & & $>7.0$ & $>7.0$ & & $>7.0$ & $>7.0$ \\
\hline Adenovirus & & $2.16 \pm 0.19 *$ & $>7.76$ & & $>7.62$ & $>7.62$ & & $>7.62$ & $>7.62$ \\
\hline Cryptosporidium & & $>2.98$ & & & & & $>2.98$ & & \\
\hline
\end{tabular}

* Arithmetic mean plus or minus one standard deviation for triplicate experiments. All other results are without replicates. ** "Greater than" sign (>) indicates total kill achieved.

Table 4. Effect of WTP pond water on log reduction values for male specific coliphage (MS2), Escherichia coli and Cryptosporidium in laboratory trials at different temperatures and contact times.

\begin{tabular}{|c|c|c|c|c|c|c|c|c|c|c|}
\hline \multirow{4}{*}{ Infectious Agent } & \multirow{4}{*}{ Pond Water } & \multicolumn{9}{|c|}{ Temperature $\left({ }^{\circ} \mathrm{C}\right)$} \\
\hline & & \multicolumn{3}{|c|}{55} & \multicolumn{3}{|c|}{65} & \multicolumn{3}{|c|}{75} \\
\hline & & \multicolumn{3}{|c|}{ Contact Time (Seconds) } & \multicolumn{3}{|c|}{ Contact Time (Seconds) } & \multicolumn{3}{|c|}{ Contact Time (Seconds) } \\
\hline & & 5 & 30 & 60 & 5 & 30 & 60 & 5 & 30 & 60 \\
\hline \multirow[t]{2}{*}{ MS2 } & $\mathrm{P} 2$ & & & & -0.05 & 0.09 & 0.82 & 1.05 & 5.56 & $>7.05^{* *}$ \\
\hline & P10 & & & & -0.03 & 0.16 & 0.66 & 1.04 & 5.66 & $>6.98$ \\
\hline \multirow{2}{*}{ E. coli } & $\mathrm{P} 2$ & 0.31 & & 0.47 & 1.04 & & $>6.61$ & $>6.61$ & & $>6.61$ \\
\hline & P10 & 0.14 & & 0.25 & 1.02 & & $>6.40$ & $>6.40$ & & $>6.40$ \\
\hline \multirow[t]{2}{*}{ Cryptosporidium } & $\mathrm{P} 2$ & & $>2.58$ & & & & & & & \\
\hline & P10 & & $>2.46$ & & & & & & & \\
\hline
\end{tabular}


Table 5. Effect of turbidity on $\log$ removal values $(L R V)$ at $60^{\circ} \mathrm{C}$ for three replicate experiments, native E. coli.

\begin{tabular}{ccc}
\hline \multirow{2}{*}{$\begin{array}{c}\text { Turbidity } \\
\text { (NTU) }\end{array}$} & \multicolumn{2}{c}{$\begin{array}{c}\text { Time } \\
\text { (Minutes) }\end{array}$} \\
\cline { 2 - 3 } & $\mathbf{3 0}$ & $\mathbf{6 0}$ \\
\hline 2.08 & 1.90 & 6.65 \\
& 1.90 & 6.54 \\
& 1.15 & 6.97 \\
\hline 14.6 & 2.14 & 6.91 \\
& 1.58 & 6.86 \\
& 1.08 & 6.82 \\
\hline$t$-test $\mathrm{P}$ & 0.90 & 0.35 \\
\hline
\end{tabular}

\subsection{Pilot Scale Testing}

The primary aims for the pilot plant trials were to test the effectiveness of the WP process for the treatment of unfiltered secondary effluent, and to assess the changes in energy efficiency resulting from the fouling of the heat exchangers.

\subsubsection{Contact Chamber Tests}

The pilot plant was operated at Melbourne's Eastern Treatment Plant (ETP) at temperatures between $69^{\circ} \mathrm{C}$ and $75^{\circ} \mathrm{C}$ with a contact chamber time of $30 \mathrm{~s}$ (flow at $\left.\sim 1100 \mathrm{~L} / \mathrm{min}\right)$ or $60 \mathrm{~s}(\sim 550 \mathrm{~L} / \mathrm{min})$. The results are shown in Figure 2.

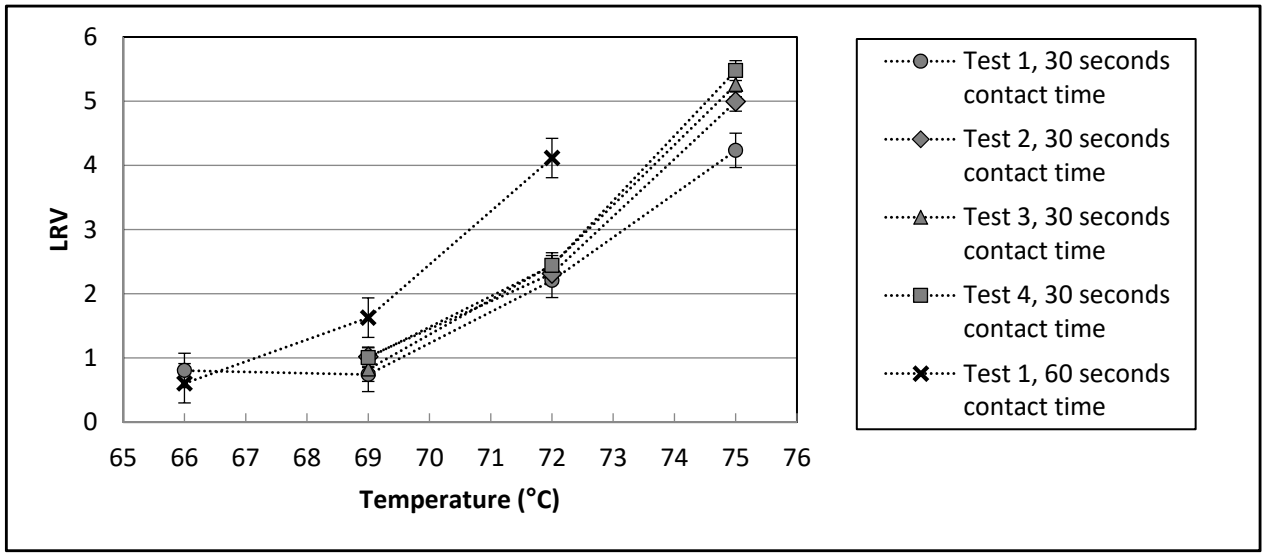

Figure 2. MS2 inactivation between Ports 4 and 5 (see Figure 1d). The high flow challenge tests ( $1100 \mathrm{~L} / \mathrm{min})$ were conducted on four separate days, each with contact time of $30 \mathrm{~s}$. The low flow challenge test ( $\sim 550 \mathrm{~L} / \mathrm{min})$ was conducted on one day at a contact time of $60 \mathrm{~s}$. All data points represent the $L R V$ calculated from the average of 6 before-treatment and 6 after-treatment samples. Error bars are one standard deviation.

The pilot plant was found to have good control of both temperature and flow during the challenge test, with relative standard deviations of $\sim 0.2 \%$ and $2 \%$ respectively. The standard deviation from the average $L R V$ values was generally found to be greater for the higher temperatures, reflecting the greater error in enumeration of low numbers of microorganisms, which are approaching the limit of detection. There was generally good agreement between the high flow (30 s contact time) LRVs obtained on four different days.

As expected, the $L R V$ values at the lower flow rate $(571 \mathrm{~L} / \mathrm{min}$, contact time of $60 \mathrm{~s})$ were higher than those at high flow rates $(\sim 1100 \mathrm{~L} / \mathrm{min}, 30 \mathrm{~s})$. This difference, however, was lower at $66^{\circ} \mathrm{C}$ than at 
$69^{\circ} \mathrm{C}$ and $72{ }^{\circ} \mathrm{C}$. These results are in good agreement with the laboratory trials results which showed $L R V$ values less than 1 at both 30 and $60 \mathrm{~s}$ at $65^{\circ} \mathrm{C}$, and a similarly high $L R V$ at 30 and $60 \mathrm{~s}$ at $75^{\circ} \mathrm{C}$ (see Tables 3 and 4).

The MS2 LRV achieved during the pilot plant contact chamber challenge tests at $75{ }^{\circ} \mathrm{C}$ and a contact time of $30 \mathrm{~s}(5.0 \pm 0.5$,) was found to be in good agreement with the MS2 LRV achieved in the laboratory trials for Pond 2 and Pond 10 water at this contact time and temperature combination (5.56, see Table 4).

\subsubsection{Entire Plant Tests}

As shown in Figure 1d, the wastewater goes through heat exchangers before and after spending time in the contact chamber, heating it on the way in and cooling it back down to close to ambient temperature on the way out. The additional time can potentially lead to greater pathogen inactivation. To test this, and to determine the level of native E. coli inactivation in the entire plant, the MS2 challenge tests were conducted at four lower temperatures, injecting the MS2 phage at Port 1, and sampling at Port 6 (see Figure 1d for port locations). The results are shown in Figure 3.

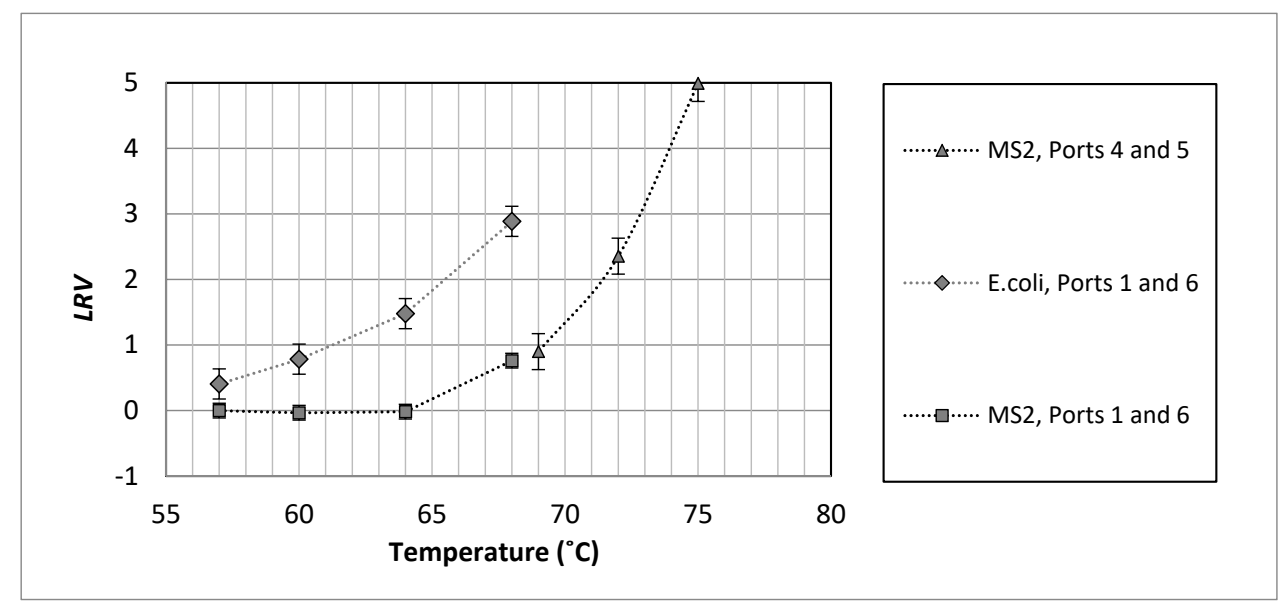

Figure 3. Comparison of disinfection performance at high flow rate, $\sim 1,100 \mathrm{~L} / \mathrm{min}$ ) for the entire plant (Ports 1 and 6, added MS2 and native E. coli, $254 \mathrm{~s}$ contact time) with the disinfection achieved in the contact chamber (between Ports 4 and 5, added MS2 phage, 30 s contact time), error bars represent one average standard deviation. See Figure $1 \mathrm{~d}$ for port locations.

An E. coli $L R V$ of $2.9 \pm 0.3$ was achieved at $68^{\circ} \mathrm{C}$ at a contact time of $254 \mathrm{~s}$ (at $1100 \mathrm{~L} / \mathrm{min}$ ). MS2 inactivation at this temperature was found to be $0.8 \pm 0.2$. The higher heat sensitivity of native $E$. coli than MS2 at the pilot plant scale confirmed the laboratory scale results (native E. coli $L R V=1.2, \mathrm{MS} 2$ $L R V=\sim 0.1$, at $65^{\circ} \mathrm{C}$ and $30 \mathrm{~s}$ contact time). The trend in E. coli $L R V s$ at varying temperatures indicated that a minimum temperature of approximately $72{ }^{\circ} \mathrm{C}$ is required for complete inactivation of the native E. coli in this water (present at $\sim 5 \log$ value $(\mathrm{LV})$, and thus achieve the high levels of treatment required for uses of recycled water that carry a high risk of direct human exposure to the wastewater. All the microbiological raw data from the laboratory and pilot tests is available from ANDS website (see the Supplementary Materials section).

\subsubsection{Energy Efficiency Changes}

The economic viability of the WP process depends largely on the efficiency of heat exchangers that recycle the heat and cool the treated water close to the ambient temperature before discharge. Poor heat exchanger efficiency results in heat loss in the effluent that must be replaced to keep the pasteurisation process running at the required temperature. Fouling of heat exchangers is a major cause of decreasing heat exchanger efficiency and the mechanism of fouling (chemical or biological) can vary depending 
on the temperature [22]. This trial was run on unfiltered wastewater from a holding basin at the end of a nitrifying/denitrifying activated sludge sewage treatment plant and can be considered to have high heat exchanger fouling potential. The feedwater was pre-filtered using a basket strainer to minimise heat exchanger fouling by large particulates. The high fouling potential was clearly evident from inspection of the basket strainer (see Figure 4), which shows almost complete occlusion of the inner surface of the basket strainer by solid matter and the protrusion of particulate and fibrous material through the $\sim 3 \mathrm{~mm}$ strainer holes.
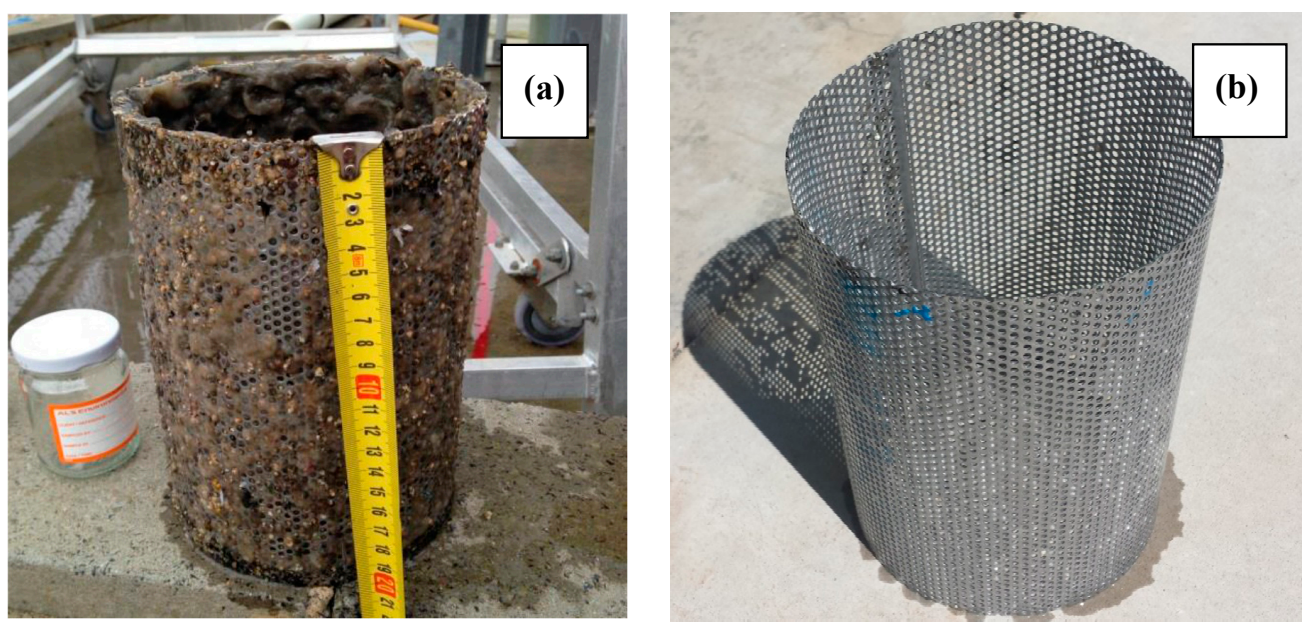

Figure 4. Appearance of the basket strainer 4 months after commissioning (a), and after cleaning immediately before performance of clean in place (CIP) procedures (b).

The measured temperature differences between the feed and the pilot plant outlet $(\Delta \mathrm{T})$ during the challenge tests, (performed at contact chamber temperature between $66^{\circ} \mathrm{C}$ and $75{ }^{\circ} \mathrm{C}$ ) and during the first continuous operation period (Period 1, constant contact chamber temperature of $72{ }^{\circ} \mathrm{C}$ ) are shown in Figure 5.

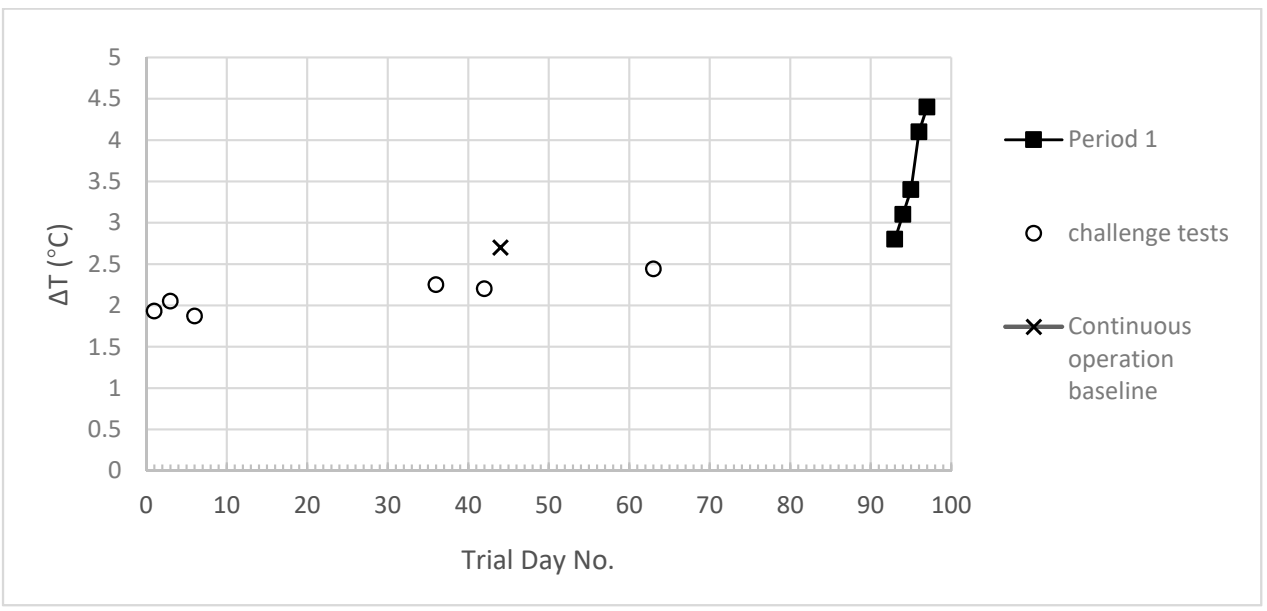

Figure 5. Temperature difference between untreated wastewater and treated wastewater outlets.

It can be seen that $\Delta \mathrm{T}$ at the first challenge test, at the start of the trial when the heat exchangers were clean, was about $2{ }^{\circ} \mathrm{C}$ and this increased to approximately $2.5^{\circ} \mathrm{C}$ by the time the last challenge test had been performed. The $\Delta \mathrm{T}$ value was found to rapidly increase during continuous operation, prompting clean in place (CIP) procedures to be implemented. The basket strainer was cleaned immediately prior to performance of the CIP procedures. The effect of different CIP procedures on the 
$\Delta \mathrm{T}$ values can be seen in Figure 6. It can be seen that the first implemented CIP (Day 108, low dose caustic solution) was effective at decreasing the $\Delta \mathrm{T}$ from 4.4 (Day 97, Figure 5) to 2.9 (Day 107, Figure 6). The $\Delta \mathrm{T}$ increased during continuous operation to 3.2 before the second CIP (high dose caustic solution) which led to a decrease in the $\Delta \mathrm{T}$ back to close to that observed at the end of the first CIP. Over the next three days, the $\Delta \mathrm{T}$ increased to 3.3 and it can be seen that the third CIP (using citric acid) was more effective than the previous caustic solution CIPs, decreasing the $\Delta \mathrm{T}$ to close to the baseline value (first continuous mode operation). The $\Delta \mathrm{T}$ value can be seen to rise rapidly over the next two days, and then increase at a slower rate over the remaining days of the continuous operation period.

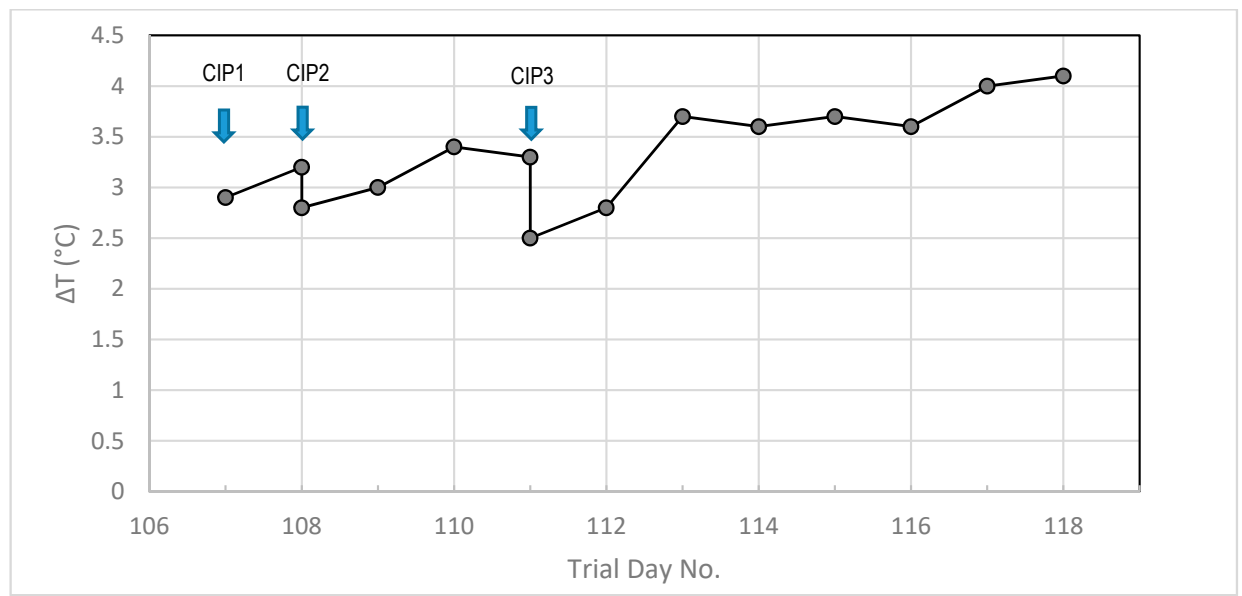

Figure 6. Effect of different $\mathrm{CIP}$ procedures on $\Delta \mathrm{T}$ during continuous pilot plant operation, $\mathrm{CP} 1$ (low strength caustic) on Day 107, CP2 (high strength caustic) on Day 108, CP3 (citric acid) on Day 111.

The observed increases in $\Delta \mathrm{T}$ values represent an increase in heat loss from the pasteurisation system and this heat must be replaced to keep the pasteurisation process running at the required temperature. Figure 7 shows the energy requirement from purchased gas as a result of heat loss in treated wastewater, with and without waste heat from current level of co-generation. Three scenarios with varying levels of supplementation of the required energy with waste energy from on-site electricity generation are considered.

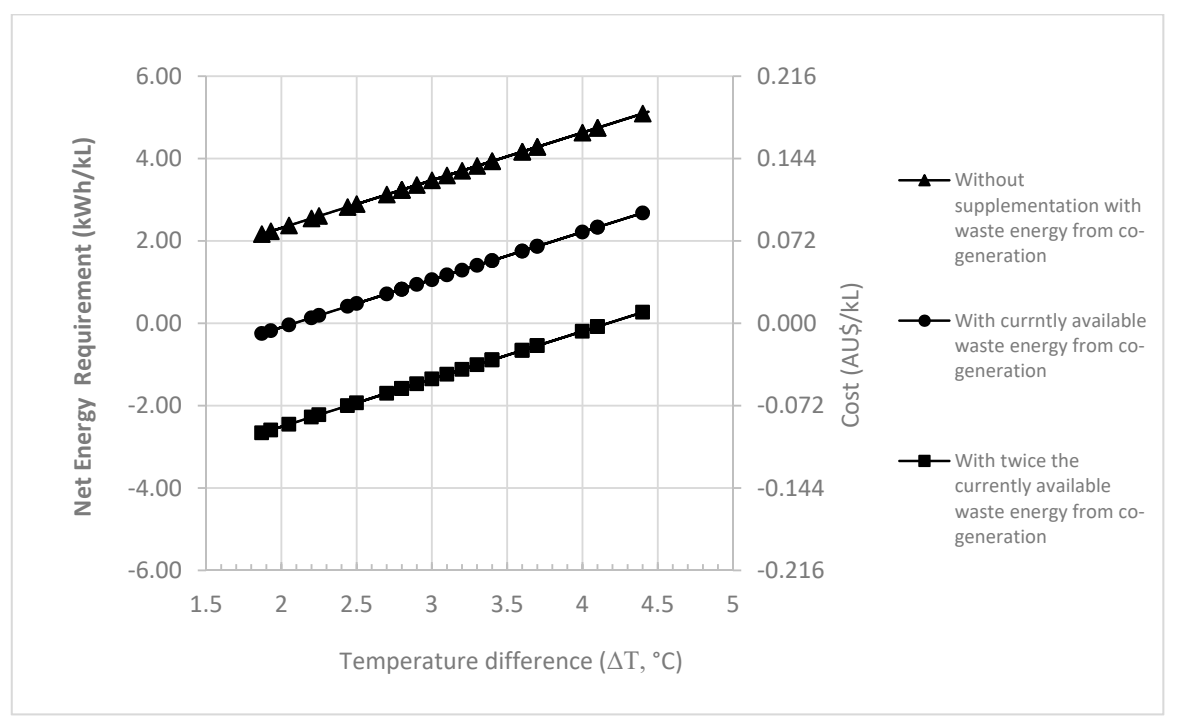

Figure 7. Energy requirement from purchased gas as a result of heat loss in treated wastewater with and without waste heat from current level of WTP co-generation (107,250 MWh/a). Cost of purchased gas requirement calculated for a gas price of $\mathrm{AU} \$ 10 / \mathrm{GJ}$ [23]. 


\section{Discussion}

These laboratory scale results are consistent with the relative heat sensitivity of the test organisms in literature [16]. Pasteurisation of raw sewage at $60{ }^{\circ} \mathrm{C}$ for $30 \mathrm{~min}$ has been found to result in MS2 LRV of 2.8, which is lower than that of faecal streptococci (3.4) and Coxsackievirus (4.8 to 5.1) [24]. The $L R V$ achieved for an environmental strain of $E$. coli (strain O148, $L R V: 4$ to 7 ) at $55^{\circ} \mathrm{C}$ for 30 min was slightly less than that of a laboratory strain of E. coli (strain NCTC 9001, LRV: 7 to 8) [25]. The milder conditions of $55^{\circ} \mathrm{C}$ for $15 \mathrm{~min}$ were found to result in Ascaris LRV inactivation greater than 3 [26]. Cryptosporidium has been found to be very sensitive to heat inactivation. Heat treatment at $55^{\circ} \mathrm{C}$ for 0.5 min has been found to achieve $L R V$ inactivation of greater than 3.

The laboratory scale data presented in Tables 3 and 4 indicates that FRNA phage may serve as a good surrogate for enteric viruses as it has a slightly higher resistance to heat than these viruses and would be a good indicator of process performance as it is the most heat resistant of the tested microbes. The data also indicates that Enterococci and E. coli could serve as a conservative surrogate for bacteria in general, with Enterococci being the more conservative surrogate. E. coli could also serve as a conservative surrogate for Cryptosporidium as it is more heat resistant.

The pilot scale $L R V$ results achieved during the current work $\left(0.9,2.4\right.$ and 5.0 at $69{ }^{\circ} \mathrm{C}, 72{ }^{\circ} \mathrm{C}$ and $75^{\circ} \mathrm{C}$ respectively) are considerably different to those achieved for the contact chamber in past pasteurisation trials at Ventura, California [3] where $L R V S$ of $5.5,7.0$ and 7.2 were reported at $72{ }^{\circ} \mathrm{C}$, $73^{\circ} \mathrm{C}$ and $79^{\circ} \mathrm{C}$ respectively, using the same strain of MS2 (strain ATCC 15597-B1) and similar contact times. There was, however, considerable agreement between the current results and those in other US studies at Graton and Santa Rosa, California ( $L R V S$ of 4.5 to 5.3 at approximately $75{ }^{\circ} \mathrm{C}$, at contact times between 15 and $40 \mathrm{~s}$ ) [27]. The observed difference between the Ventura trial data and the other trial data may possibly be attributable to the use of high seed doses in the Ventura trial, which can cause artificially high $L R V_{S}$ [28]. Another possible cause of the differences observed is a difference in water quality. The results of the 2007 Ventura wastewater pasteurisation trial suggest that turbidity plays a role in pasteurisation disinfection kinetics, particularly with regard to coliform disinfection [3]. This study compared disinfection performance of filtered and unfiltered effluent and found that unfiltered effluent required the use of higher temperatures to achieve the desired E. coli inactivation level.

Municipal wastewater treatment plants are increasingly turning to on-site renewable energy generation from biogas production. Melbourne's Western Treatment Plant, for example, has an expected annual electrical output of 71,500 MWh from the WTP biogas power plant which enables it to meet nearly all its annual electricity needs using renewable energy on site [29]. Assuming approximately $40 \%$ efficiency for electricity generation [30], and the use of approximately $90 \%$ of available waste heat energy, this on-site electricity generation leads to the generation of approximately 96,505 MWh of available waste energy that can be used for pasteurisation. Figure 7 highlights the importance of keeping $\Delta \mathrm{T}$ as low as possible and the use of waste heat from co-generation. Without supplementation of the energy for pasteurisation from co-generation, the requirement of energy from purchased gas ranges from 2.2 to $5.1 \mathrm{kWh} / \mathrm{kL}$, depending on the $\Delta \mathrm{T}$. This can be compared to the typical energy intensity of currently available advanced technologies [31] for wastewater treatment shown in Table 6. It can be seen that pasteurisation is very energy intensive when compared with a typical advanced disinfection treatment process train such as ultrafiltration (UF) + UV + ozone $(\sim 0.32 \mathrm{kWh} / \mathrm{kL})$. Supplementation of the required energy with waste energy from co-generation is required to make pasteurisation competitive with this process train from an energy intensity perspective. Figure 7 shows that a pasteurisation wastewater plant that is run at a $\Delta \mathrm{T}$ value of $2.3^{\circ} \mathrm{C}$ would require all of Melbourne Water's WTP current co-generation waste heat to be competitive with UF + UV + ozone treatment. If, however, the $\Delta \mathrm{T}$ value were allowed to increase to the levels seen in the current trial $\left(3.5\right.$ to $\left.4{ }^{\circ} \mathrm{C}\right)$ slightly more than twice the current level of co-generation would be required to make pasteurization competitive with this process train from an energy intensity perspective. 
Table 6. Typical energy intensity of advanced water treatment technology (adapted from [31]).

\begin{tabular}{cc}
\hline Advanced Treatment Technology & Energy Intensity kWh/kL \\
\hline Ultraviolet (UV) & 0.026 \\
\hline Ozone & 0.16 \\
\hline Ultrafiltration (UF) & 0.13 \\
\hline Reverse osmosis (RO) & 2.6 \\
\hline Membrane bioreactor (MBR) & 6.6 \\
\hline Electrodialysis reversal (EDR) & 2.6 \\
\hline
\end{tabular}

Clearly, the economic viability of pasteurisation for this unfiltered secondary effluent application would depend largely on the available waste heat from co-generation and on the efforts required to keep a low $\Delta \mathrm{T}$. The costs associated with CIP and pre-treatment (e.g., coagulation, filtration) will be key determinants of this economic viability.

Future implementation of this technology will depend on like-for-like comparisons of this technology with current chlorination, ozonation and UV treatment in terms of economic viability and environmental footprint in a changing regulatory, economic and environmental landscape. This comparison must, however, be seen in the light of increasing environmental awareness and the probability that the harmful DBPs produced form chlorination and ozonation, and the greenhouse gas emissions associated with the high electricity requirements of UV treatment, will be more strictly regulated in the future. The pasteurisation process's lack of production of harmful DBPs and ability to run on waste heat from on-site electricity generation from biogas may favour its future implementation.

\section{Conclusions}

FRNA phage were found to have a higher resistance to heat than viral pathogens, bacteria, protozoa and helminths and may serve as a good surrogate for enteric viruses, as conservative surrogates for bacteria, protozoa and helminths, and as good indicators of process performance. Enterococci and E. coli could serve as a conservative surrogate for bacteria in general, with Enterococci being a more conservative surrogate. E. coli could also serve as a conservative surrogate for protozoa and helminths.

Pilot scale (2ML/day) pasteurisation can be used to reduce the levels of pathogens in unfiltered secondary effluent wastewater to achieve high water quality standards. Challenge tests conducted over short periods of operation, using MS2 phage as process performance indicator and surrogate for pathogens of concern, showed that operation of the pilot plant with a contact time of $30 \mathrm{~s}$ (feed flowrate $=1100 \mathrm{~L} / \mathrm{min}$ ) and a temperature of $75^{\circ} \mathrm{C}$ can achieve an average log reduction value of 5.0 for MS2 phage. The bottom 5th percentile $L R V$ was found to be 4.0 under these conditions.

The impact of heat exchanger fouling on the efficiency of the WP process during the treatment of unfiltered secondary effluent was also studied. Small increases in the difference between the inlet wastewater temperature and the treated wastewater temperature $(\Delta \mathrm{T})$ resulting from heat exchanger fouling were found to markedly increase the energy requirement. These $\Delta \mathrm{T}$ values were found to increase rapidly over the duration of the test period, indicating that the unfiltered secondary effluent used in this study had high fouling potential. The economic viability of pasteurisation for the current municipal application will depend largely on the available waste heat from co-generation and on the efforts and expense required to keep the $\Delta \mathrm{T}$ low. The costs associated with pre-treatment (e.g., coagulation, filtration) to minimise the fouling potential of the feedwater and/or with the CIP requirements to maintain a low $\Delta \mathrm{T}$ will be key determinants of the economic viability of the WP process. 
Supplementary Materials: Australian National Data Service, Research Data Australia Registry, website: https: //researchdata.ands.org.au/pasteurisation-production-class-recycled-water/671971.

Author Contributions: Conceptualization, J.B. and S.G.; formal analysis, P.S. and P.M.; funding acquisition, J.B. and S.G.; investigation, P.S., J.L., G.R. and A.S.; methodology, P.S., P.M., G.R., A.S., N.F. and S.G.; project administration, P.S. and S.G.; resources, J.B.; supervision, S.G.; writing — original draft, P.S. and P.M.; writing-review and editing, P.S., P.M., G.R., A.S., N.F., J.B. and S.G. All authors have read and agreed to the published version of the manuscript.

Funding: This research was funded by the Australian Water Recycling Centre of Excellence. Melbourne Water contributed to this research project as collaborating project partner. The Article Processing Charge was funded by Victoria University.

Acknowledgments: The authors would like to thank Melbourne Water for hosting the pilot plant trial.

Conflicts of Interest: The authors declare no conflicts of interest. The funders had no role in the design of the study; in the collection, analyses, or interpretation of data; in the writing of the manuscript, or in the decision to publish the results.

\section{References}

1. Natural Resource Management Ministerial Council. Environment Protection and Heritage Council, Australian Health Minister's Conference, Australian Government, Australian Guidelines for Water Recycling: Managing Health and Environmental Risks (Phase 1); Environment Protection and Heritage Council: Adelaide, South Australia, Australia, 2006.

2. The Water Research Foundation, Leaders Innovation Forum for Technology. Available online: https: //www.waterrf.org/news/pasteurization-technology-group (accessed on 1 June 2020).

3. Salveson, A. Use of Pasteurization for Pathogen Inactivation for Ventura Water. In 2012 Guidelines for Water Reuse; EPA/600/R-12/618; US EPA Office of Research and Development: Washington, DC, USA, 2012; p. D-55.

4. Da Costa, J.B.; Rodgher, S.; Daniel, L.A.; Espíndola, E.L. Toxicity on aquatic organisms exposed to secondary effluent disinfected with chlorine, peracetic acid, ozone and UV radiation. Ecotoxicology 2014, 23, 1803-1813. [CrossRef] [PubMed]

5. Abou-Elela, S.I.; El-Sayed, M.M.H.; El-Gendy, A.S.; Abou-Taleb, E.M. Comparative Study of Disinfection of Secondary Treated Wastewater Using Chlorine, UV and Ozone. J. Appl. Sci. Res. 2012, 8, 5190-5197.

6. Blatchley, E.R.; Hunt, B.A.; Duggirala, R.; Thompson, J.E.; Zhao, J.; Halaby, T.; Cowger, R.L.; Straub, C.M.; Alleman, J.E. Effects of disinfectants on wastewater effluent toxicity. Water Res. 1997, 31, 1581-1588. [CrossRef]

7. Gray, N.F. Ozone Disinfection in Microbiology of Waterborne Disease, Microbial Aspects of Risks, 2nd ed.; Percival, S.L., Yates, P.V., Williams, D.W., Chalmers, R.M., Gray, N.F., Eds.; Academic Press: Cambridge, MA, USA, 2014; Chapter 33; pp. 599-615.

8. Gray, N.F. Ultraviolet Disinfection in Microbiology of Waterborne Diseases, Microbial Aspects of Risks, 2nd ed.; Percival, S.L., Yates, P.V., Williams, D.W., Chalmers, R.M., Gray, N.F., Eds.; Academic Press: Cambridge, MA, USA, 2014; Chapter 34; pp. 617-630.

9. Den Besten, H.M.W.; van der Mark, E.J.; Hensen, L.; Abee, T.; Zwietering, M.H. Quantification of the Effect of Culturing Temperature on Salt-Induced Heat Resistance of Bacillus Species. Appl. Environ. Microbiol. 2010, 76, 4286-4292. [CrossRef] [PubMed]

10. Juneja, V.K.; Altuntaş, E.G.; Ayhan, K.; Hwang, C.A.; Sheen, S. Mendel Friedman predictive model for the reduction of heat resistance of Listeria monocytogenes in ground beef by the combined effect of sodium chloride and apple polyphenols. Int. J. Food Microbiol. 2013, 164, 54-59. [CrossRef] [PubMed]

11. Volkin, D.B.; Burke, C.J.; Marfia, K.E.; Oswald, C.B.; Wolanski., B.; Middaugh, C.R. Size and conformational stability of the hepatitis A virus used to prepare VAQTA, a highly purified inactivated vaccine. J. Pharm. Sci. 1997, 86, 666-673. [CrossRef] [PubMed]

12. Institute of Food Technologists for the Food and Drug Administration of the U.S. Department of Health and Human Services, Kinetics of Microbial Inactivation for Alternative Food Processing Technologies. J. Food Sci. 2000, 65 (Suppl. S8), 16-31.

13. Kaur, J.; Ledward, D.A.; Park, R.W.; Robson, R.L. Factors affecting the heat resistance of Escherichia coli O157:H7. Lett. Appl. Microbiol. 1998, 26, 325-330. [CrossRef] [PubMed] 
14. Shen, C.; Geornaras, I.; Belk, K.E.; Smith, G.C.; Sofos, J.N. Thermal Inactivation of Acid, Cold, Heat, Starvation, and Desiccation Stress-Adapted Escherichia coli O157:H7 in Moisture-Enhanced Nonintact Beef. J. Food Prot. 2011, 74, 531-538. [CrossRef] [PubMed]

15. US EPA Office of Research and Development. 2012 Guidelines for Water Reuse; EPA/600/R-12/618; US EPA Office of Research and Development: Washington, DC, USA, 2012.

16. Lau, M.; Monis, P.; Ryan, G.; Salveson, A.; Blackbeard, J.; Gray, S.; Sanciolo, P. Selection of surrogate pathogens and process indicator organisms for pasteurisation of municipal wastewater-A survey of literature data on heat inactivation of pathogens. Process. Saf. Environ. Prot. 2020, 133, 301-314. [CrossRef]

17. Kahler, A.M.; Cromeans, T.L.; Roberts, J.M.; Hill, V.R. Source water quality effects on monochloramine inactivation of adenovirus, coxsackievirus, echovirus, and murine norovirus. Water Res. 2011, 45, 1745-1751. [CrossRef] [PubMed]

18. King, B.J.; Keegan, A.R.; Robinson, B.S.; Monis, P.T. Cryptosporidium cell culture infectivity assay design. Parasitology 2011, 138, 671-681. [CrossRef] [PubMed]

19. Jeska, E.L.; Caruso, J.P.; Donohue, M.J. Collection of fertile Ascaris suum eggs. J. Parasitol. 1986, 72, 964-965. [CrossRef] [PubMed]

20. USEPA. Office of Water, Guidance Manual for Disinfection Profiling and Benchmarking; EPA 815-R-99-013; USEPA: Washington, DC, USA, 1999.

21. Department of Health, Government of State of Victoria. Guidelines for Validating Treatment Processes for Pathogen Reduction-Supporting Class a Recycled Water Schemes in Victoria; Department of Health, Government of State of Victoria: Melbourne, Victoria, Australia, 2013.

22. Cunault, C.; Burton, C.H.; Pourcher, A.M. The impact of fouling on the process performance of the thermal treatment of pig slurry using tubular heat exchangers. J. Environ. Manag. 2013, 117, 253-262. [CrossRef] [PubMed]

23. Australian Energy Regulator. Report 14-20; Australian Energy Regulator: Melbourne, Australia, 2018.

24. Moce-Llivina, L.; Muniesa, M.; Pimenta-Vale, H.; Lucena, F.; Jofre, J. Survival of Bacterial Indicator Species and Bacteriophages after Thermal Treatment of Sludge and Sewage. Appl. Environ. Microbiol. 2003, 69, 1452-1456. [CrossRef] [PubMed]

25. Lang, N.L.; Smith, S.R. Time and temperature inactivation kinetics of enteric bacteria relevant to sewage sludge treatment processes for agricultural use. Water Res. 2008, 42, 2229-2241. [CrossRef] [PubMed]

26. Sahlstrom, L.; Bagge, E.; Emmoth, E.; Holmqvist, A.; Danielsson-Tham, M.L.; Albihn, A. A laboratory study of survival of selected microorganisms after heat treatment of biowaste used in biogas plants. Bioresour. Technol. 2008, 99, 7859-7865. [CrossRef] [PubMed]

27. Pasteurization Technology Group. Available online: https://www.ptgwe.com/wp-content/uploads/2017/08/ Pasteurization_Melbourne-Water-and-WaterRF-Updates-WEFTEC-2015.pdf (accessed on 1 June 2020).

28. USEPA. Office of Water, Membrane Filtration Guidance Manual; EPA 815-R-06-009; USEPA: Washington, DC, USA, 2005.

29. Melbourne Water. 2018. Available online: https://medium.com/mark-and-focus/melbourne-waterharnessing-renewable-energy-b6aab6809b71 (accessed on 1 June 2020).

30. GE-Jenbacker Gas Engines Technical Description. 2007. Available online: http://www.provincia.livorno.it/ new/spawdocs/ambiente/Technical\%20Description_AB\%20Energy\%20320.pdf (accessed on 1 June 2020).

31. Hallet, C.K. Energy intensity of water: Literature suggests increasing interest despite limited and inconsistent data. In Proceedings of the ASME 2011 International Mechanical Engineering Congress \& Exposition IMECE2011, Denver, CO, USA, 11-17 November 2011.

(C) 2020 by the authors. Licensee MDPI, Basel, Switzerland. This article is an open access article distributed under the terms and conditions of the Creative Commons Attribution (CC BY) license (http://creativecommons.org/licenses/by/4.0/). 